\title{
A MULTIMODAL SEMIOTIC DISCOURSE ANALYSIS TO REVEAL SEXUAL HARASSMENT ON DIRECT MESSAGE OF SOCIAL MEDIA
}

\author{
Ayu Lityaningrum \\ Graduate Student, Linguistics Department, University of Indonesia, Depok, Indonesia \\ e-mail: Lityaningrumayu98@gmail.com
}

\begin{abstract}
ABSTRAK
Adanya pelecehan seksual selama pandemi melalui media sosial perlu perhatian khusus bagaimana pesan tersebut dapat diyakini sebagai pelecehan seksual layaknya pada dunia nyata dengan berbagai ragam gabungan moda seperti tulisan yang disertai dengan emoji. Dengan demikian, penelitian ini bertujuan untuk mendeskripsikan hubungan unsur verbal dan visual dalam membentuk tindakan pelecehan seksual yang dilakukan pelaku dari segi linguistik sehingga dapat dihubungkan dengan Pasal yang dijatuhkan kepada terdakwa apabila kasus dibawa melalui jalur hukum. Metode penelitian ini menggunakan kualitatif dengan teknik pengumpulan data menggunakan studi pustaka. Data yang digunakan adalah bukti pesan dengan indikasi pelecehan seksual terhadap korban yang di dalamnya mengandung unsur verbal dan visual yang berupa emoji. Dalam menganalisis data, peneliti menggunakan teori multimodalitas khususnya makna ideasional dan interpersonal oleh Kress \& Leeuwen (2006) dan Halliday \& Mathiessen (2004). Penelitian ini terbatas pada ujaran pelaku dan terbatas pada tataran makna Ideasional dan Interpersonal. Hasil yang didapat adalah hubungan kedua moda terlihat dari unsur visual berupa emoji yang dapat memperjelas adanya pelecehan seksual secara verbal melalui media sosial. Hal ini dilihat dari adanya unsur visual yang mengekstensi dan menerangkan unsur verbal. Selain itu, adanya temuan bahwa emoji dapat menjadi alat bukti untuk mengungkap kejahatan melalui bahasa.
\end{abstract}

Keywords:

Forensic

Linguistics, Multimodality, Social Media, Sexual Harassment

\section{INTRODUCTION}

Nowadays, the existence of social media in daily life has a positive impact, such as freedom to express opinions in various ways in the form of a short text that includes information, control devices, motivation, and records of emotional expression (Robbins, 2014). Instagram, Twitter, and Facebook are the types of social media that are widely used. In addition, in today's modern era, the use of emoji features in social media is often considered a part that fills the gaps in verbal mode and makes it easier to express emotions and ideas effectively and interestingly which is called as the popular language (Danesi, 2017). On the other hand, it may have negative impacts. 


\section{SASDAYA}

Gadjah Mada Journal of Humanities, Vol. 5. No. 2, 2021

For example, due to the freedom of expression, many users do not heed the limits of opinion that they can publicly share. Through social media, cases of verbal sexual harassment prove this statement, which initiates the Electronic Information and Transaction Law (UU ITE).

In a nutshell, sexual harassment is a kind of violation that leads to sexual activity without the other party's consent, and it does not have to result in rape (Shuy, 2012). However, there is a lack of clarity about the boundaries of sexual harassment in Indonesia. If sexual harassment is verbally done, it is included in Article 27 paragraph (3) of the ITE Law regarding insults or defamation as long as the sexual violence bill (RUU PKS) has not been ratified, the before mentioned Article deals with acts of verbal sexual harassment. Concerning forensic linguistics, where language becomes linguistic evidence in solving cases (Olsson, 2008), verbal harassment can be evidence in the court as the case through legal channels.

The existence of the law mentioned above does not seem to have such a serious deterrent effect. It is also proven by the increasing number of sexual harassment cases with a new pattern that is quite extreme for women to accept, both verbally and non-verbally, through online media during the pandemic (Komnas Perempuan National Commission On Violence Against Women, 2021). The prominent evidence is the existence of sexual harassment victims who were harassed by anonymous accounts on social media. Everyone can access easily using social media and can be another person that they want to create themselves. Therefore, anonymous account can be easily to be found in any social media such as Instagram.

Instagram is one of the social media that still exist nowadays. There are many people still using this social media because it contains lots of feature that can be accessed for everyone. Starting from photo and video that contain any activities which can be seen by any user of Instagram. Moreover, the photo and video in Instagram also can be replied or responded too. This activity that can lead to sexual harassment depends on which video or photo that the user shared, but it is important to see from many perspectives to decide whether it contains sexual harassment or not.

The case of this research stars from a person (it can be identified as the victim) who shared a selfie photo in Instagram story. The uploaded photo is not contain any sexual activities but there is a respond from anonymous account which contain sexual harassment message. The form of harassment received by the victim is verbal sexual harassment that contains repeated obscene messages through Instagram social media. Not only messages, but perpetrators also tend to use emojis in every message sent. Since Instagram is one of the social media that is in demand from various circles (Frommer, 2021), it is possible for anyone who intentionally creates an anonymous account and sends specific messages through a feature called DM (Direct Message). With the perpetrator's identity being unknown, the victim has the urge to reply to the messages using harsh language, which ends with blocking the perpetrator's account.

Thus, the problem of this study is that the anonymous perpetrator's utterances sent via Instagram direct message containing verbal and visual modes that indicate sexual harassment in a verbal form. Particular articles can bind these actions in language crimes through social media. Moreover, the purpose of the study aims to describe the relationship between verbal and visual modes in creating acts of sexual harassment by perpetrators from a linguistic point of view. So, the action could be linked to the article handed down to the defendant if it is brought 


\section{SASDAYA}

Gadjah Mada Journal of Humanities, Vol. 5. No. 2, 2021

to the court. This research is limited to verbal and visual utterances sent by the perpetrators, while the analysis is limited to the ideational and interpersonal meanings.

The previous research on multimodal with emojis Gumono entitled 'Penggunaan Bahasa Dalam Pesan Whatsapp: Interaksi Multimodal' Language in Whatsapp Messages (Oktario et al., 2019), mainly focusing on multimodal interaction. The method used is qualitative. The data analyzed were limited to visual emoji mode and Interpersonal meaning. The results showed the use of visual mode in emoji as many as 20 characters in 10 classifications with different purpose. Another multimodal research is concern about advertisement. There are several researchers who conducted multimodal analysis using advertisement. Those research are entitled A Multimodal Discourse Analysis of The Interpersonal meaning of A Television Advertisement in Indonesia, 'Analisis Multimodal pada Iklan Sunsilk Nutrien Sampo Ginseng' Multimodal Analysis in Sunsilk Shampoo Advertisement, and 'Analisis Multimodal Iklan Indomie' Multimodal Analysis in Indomie Advertisement (Hidayat et al., 2019; Rosa, 2014; Suprakisno, 2010). Those researchers showed the result of their study which visual and verbal mode such a complex term that cannot separated from advertisement to make the advertisement successful. Visual and verbal elements are the important things that could attract audiences' attention. So, the use of multimodal approach is suitable in order to analyse the data.

Therefore, this research is important to be conducted because previous studies are still not much discussing further about sexual harassment using multimodal approach. If the researcher looks at the first previous study about multimodal analysis in Whatsapp by Oktario, A. S., Ariesta, R., and Gumono (2019), the gap between the study and this study is in the mode of the previous research is only focusing in visual mode while this study is concerning in visual and verbal mode.

Next, the previous studies are also not discussing further about forensic linguistics. Advertisement and chatting using social media is not part of forensic linguistics. Furthermore, this research is also using data from social media which is challenging. Besides, using social media as data of this study is also challenging because it needs a complex analysis steps to make easy to interpret and comprehend as in real life (Yus, 2020). The analysis is to make easy in order to explain how communication through virtual can be understood as communication in real life. It relates with how sexual harassment through social media can be understood as sexual harassment in real life. Perhaps it does not need real activity, but from a power of language it can be judge as language crime (Danesi, 2017).

So, the corelation between visual and verbal elements in a discourse cannot be separated. Both elements are the key to be analysed in order to reveal verbal sexual harassment case. Therefore, this study needs to know how relationship between verbal and visual mode in order to reveal this case from linguistic point of view. The result of this study can be used as model of multimodal analysis. Then, it is also can be used as model of forensic linguistics analysis.

\section{METHOD AND THEORETICAL FRAMEWORK}

A qualitative approach was used in this study to obtain more in-depth results by describing the phenomenon of sexual harassment that occurred (Creswell, 2002). The method used in data collection is the documentation technique. The document needed are obtained using Twitter 


\section{SASDAYA}

Gadjah Mada Journal of Humanities, Vol. 5. No. 2, 2021

advanced search feature. Twitter's advanced search feature is a feature to get tweets with categories defined by users.

According Olsson, forensic linguistics is how linguists can make an essential contribution in uncovering a case (Olsson, 2008). Forensic linguistics is a field of analysing the language that can be linguistic evidence that can help courts uncover the case. Therefore, it can be said that through forensic linguistics, linguist study texts that intersect with the law. It also means that texts can be analysed using linguistic sub-fields, one of which is discourse analysis. When viewed from the social context, language is a sign that is shared socially; thus, it is referred to as social semiotics (Alexander \& Halliday, 2014). Language modes include spoken forms or sound of language and written or spelled punctuation. In its delivery, it can be combined with other modal signs. Thus, it is called as multimodality, or a combination of modes in conveying a sign, a message using more than one mode in a discourse. That is, in a discourse can contain verbal and visual modes (Kress \& Leeuwen, 2006). Therefore, the form of the data includes verbal and non-verbal elements, so it is interesting to investigate further.

Verbal element is in the form of phrase, sentence, and clause which contains sexual harassment activity. Then, the visual element is in the form of emoji which followed by verbal element that contains sexual harassment activity. The data source is screenshot of direct message Instagram messages uploaded through the victim's Twitter social media account. Then, the data sources used in this study are divided into two, namely primarily and secondary data. The primary data are screenshots with indications of sexual harassment obtained through the victim's Twitter account. Next, secondary data used is in the form of comments that appear on the top four replies of the tweets from the victim's Twitter account to validate the data analysis result. The primary data can be seen in Figure 3 below.

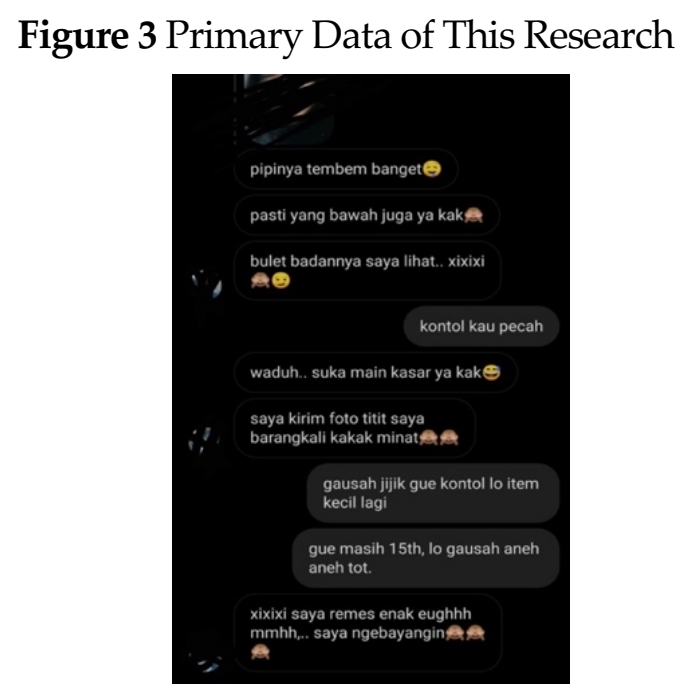

In analysing the data, the researcher used the multimodal theory of Kress \& Leeuwen (2006). To make the analysis easier, the first stage was done by analysing the verbal mode in the data by dividing them from the minor elements in the form of word, phrase, and clauses depends on the data. The verbal mode can be analysed using ideational, interpersonal, and textual meanings or called as metafunction (Halliday, 2014). In other word, the first step of the analysis verbal mode is analysing the ideational meaning or transitivity.

Transitivity is at the level of ideational meaning of verbal mode. Further, it is the relationship between process, participant, and circumstance (optional) (Yuwono, 2019). According to Halliday, 


\section{SASDAYA}

Gadjah Mada Journal of Humanities, Vol. 5. No. 2, 2021

clause is a unit of social representation. By looking at the transitivity, it can be shown what is going on in the clause (Halliday, 2014). Then, the centre of a clause is a Process that consist of material, mental, relational (attributive and identifying), behavioural, verbal, and existential processes. Each process has its participant label. To make understand about transitivity system can look at the Figure 1.

Figure 1 Transitivity by Halliday and Mathiessen (2014)

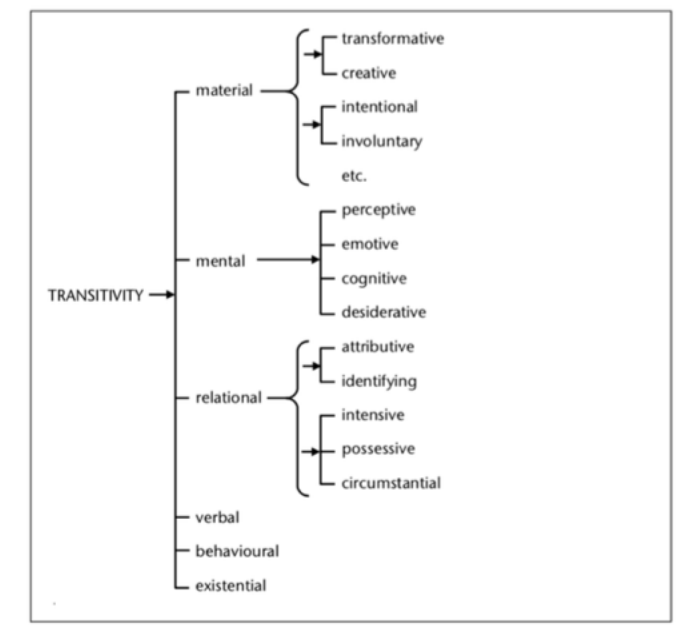

After ideational meaning was done to be analysed, the researcher continued with the interpersonal meaning analysis of the verbal data. The level of interpersonal meaning of verbal mode includes the function of discourse as demand, give, and offer. The basic mood consist of indicative and imperative. Indicative mood divided as declarative and interrogative. Each mood can contain either a positive or negative polarity if using any modality markers. There is also a residue split into predicator, complement, and adjunct in the mood system. To make understand about basic mood types, the Figure 2 below is about the basic mood types following with the characteristic itself.

Figure 2 Basic Mood Types by Halliday and Matthiessen (2014)

\section{Basic MOOD types}

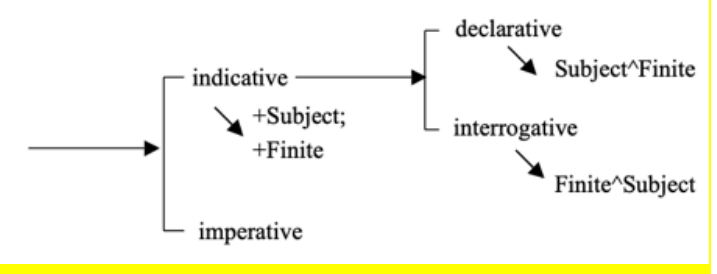

Not only verbal mode, but the visual mode can also be analysed by noticing the ideational, interpersonal, and textual meaning of it (Kress \& Leeuwen, 2006). After analysing the verbal mode, the researcher analysed the visual mode, starts with analysing the ideational or representational meanings analysis and continues with the interpersonal meanings analysis. The first step of analysing visual mode is analysing the ideational meaning

At the level of ideational meaning on visual mode called as representational, is divided into narrative and conceptual representation. Narrative representations are seen when connected by 


\section{SASDAYA}

Gadjah Mada Journal of Humanities, Vol. 5. No. 2, 2021

vectors, or narrative feature, of the represented participants conducting an activity. Moreover, it is divided into action, reactional, verbal, and mental processes. Furthermore, the conceptual representation in which the participant appear is represented in a more stable or fixed state and it is not bound by time. There are three main processes in conceptual representation, namely the classificational, analytical, and symbolic processes. There are two participants in visual modes, represented and interactive participants.

After ideational meaning was done to be analysed, the researcher continued with the interpersonal meaning analysis of the visual data. Interpersonal meaning in the visual mode includes the participant's eyes or gaze, both displayed and interactive, as a function of discourse to determine whether the visual mode contains demand or offer. Apart from that, there are frame of sizes to realize the social distance between represented and interactive participant. Including close-shots, medium-close shots, medium shots, and long shots. The farther away the represented participant is, the father of the social distance between the represented and interactive participant or reader. In addition, there is angle that represents the power relationship between the represented and interactive participant. They are low, eye level, and high angle.

In order to analysis the visual data, the researcher also used the supported theory. According to the visual data of emoji, emoji comes from Japanese adaptation word consisting of $e$, which means picture and moji, meaning letters or characters. So, emoji implies a word in form of an image (Danesi, 2017). In the life of the digital era, there seems to be an urgency to include emoji to display a new and contemporary style of writing and communication. The use of emoji explicitly gives a person the freedom to use it as he wishes, which also means that it as he wishes, which also means that it can be used as evidence in court trials. Besides, its functions are divided into a phatic function: maintaining communication and an emotive function, which means expressing emotions.

\section{FINDINGS AND DISCUSSIONS}

By using multimodality analysis, the researcher has attached some results and discussions, as follows.

Figure 4 Ideational and Interpersonal Analysis of Verbal Mode Datum 1

\begin{tabular}{|c|c|c|}
\hline Pipinya & [berbentuk] & tembem banget \\
\hline Subject & Predicator & Complement \\
\hline \multicolumn{2}{|c|}{ MOOD } & RESIDUE \\
\hline Participant: Carrier & Process: Relational & Participant: Attributive \\
\hline
\end{tabular}

The Figure 4 above is the analysis of ideational and interpersonal of the verbal datum. From the analysis, the data that reads 'pipinya tembem banget' your checks are so chubby results from the transitivity analysis obtained as a relational process. The relational process was chosen because 'berbentuk' or shaped implies being or explaining the carrier participant, namely 'pipinya' or the checks. The carrier participant is defined by 'shaped', which is equipped with the attribute 'tembem banget' or so chubby. Process [in the form of] there is a sign " $[$ ]" because it is absorbed in the data, so the researcher should appear it. The results of interpersonal meaning can be seen that the utterance is in the form of declarative. A predicator follows the subject pattern with the meaning containing information related to one of the victim's body parts. The choice of the word 'tembem banget' or so chubby is related on the next datum or the 


\section{SASDAYA}

Gadjah Mada Journal of Humanities, Vol. 5. No. 2, 2021

next message. To avoid ambiguity, the message's sender can use literary the word of 'chubby' without additional word 'so', which seems to only aim at the checks, and does not relate with other body parts.

Next, Figure 5 below is the visual element that following the verbal mode in Datum 1 . The emoji used by perpetrator in the message especially is called as Drooling emoji.

Figure 5 Ideational and Interpersonal Analysis Visual Mode Datum 1

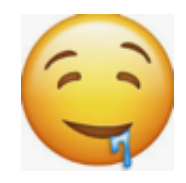

The Drooling emoji is a face emoji with a slightly drooling expression. Based on the representational analysis or the ideational analysis, this emoji contains narrative representations, especially Non-transactional reactions, and the conceptual representations, especially in suggestive symbolic processes. Non-transactional representation means that the interactive participant at does not appear. It means that the represented participant's eye is in line with the interactive participant's eye. The representation of suggestive symbolic process indicates that only one participant appears as a carrier and it is not bound by time. The emoji does not change at any time, and only one emoji is visible. In addition, the emoji comes with a verbal mode. Universally, the emoji means desire which is connected with Interpersonal meaning. At the first glance, it looks like there is no eye contact, but it is actually show a few eyes. Therefore, it is implied a demanding. The size of the emoji frame is a close-shot because only the face is displayed with the meaning of the closeness of social distance which built by the sender of the message. Meanwhile, the angle in the datum is eye-level or in line with the message reader or interactive participant

By combining the two modes, the visual mode extends the verbal mode in the message. Further, the extension means adding an idea. The main idea contained in the emoji states that there is a positive opinion or an agreeable attitude towards the shape of the victim's checks, resulting in an expression of interest and wanting to be added with a 'tembem banget' so chubby as complement, which can be said as a statement of praise. In this case, the perpetrator wants to add a new idea that he used an emoji with an emotive function to express the desire and describe other request that lead to sexuality aimed at the victim. Moreover, it also instils obscene thoughts since they are attracted to the victim's body parts.

The next Datum analysis is in the Figure 6 and Figure 7 below.

Figure 6 Ideational and Interpersonal Analysis of Verbal Mode Datum 2

\begin{tabular}{|c|c|c|c|c|c|}
\hline Pasti & yang & bawah & \multicolumn{2}{|c|}{\begin{tabular}{l|l} 
juga & [[berbentuk \\
\end{tabular}} & tembem banget]] \\
\hline \multirow[t]{5}{*}{ Modal } & \multicolumn{2}{|l|}{ Subject } & \multicolumn{2}{|c|}{ Predicator } & Complement \\
\hline & \multirow{2}{*}{\multicolumn{2}{|c|}{\begin{tabular}{c|c} 
Conjunction & Adjunct \\
MOOD
\end{tabular}}} & & & \\
\hline & & & \multirow{2}{*}{\multicolumn{3}{|c|}{ RESIDUE }} \\
\hline & & & & & \\
\hline & \multicolumn{2}{|c|}{ Participant: Carrier } & \multicolumn{2}{|c|}{ Process: Relational } & Participant: Attribute \\
\hline \multicolumn{2}{|c|}{ [Pernyataan sebelumnya] } & \multicolumn{2}{|c|}{ ya (benar) } & [kan] & kak? \\
\hline \multirow{2}{*}{\multicolumn{2}{|c|}{ Complement }} & Predica & ator & Operator Modal & Subject \\
\hline & & \multicolumn{4}{|c|}{ MOOD } \\
\hline \multicolumn{5}{|c|}{ RESIDUE } & \\
\hline \multicolumn{2}{|c|}{ Participant: Phenomena } & Process & s: $\mathrm{Me}$ & & Participant: Senser \\
\hline
\end{tabular}

The Figure 6 above is the analysis of ideational and interpersonal of the next verbal datum. Datum 'pasti yang bawah juga ya kak' or the bottom one of yours is big too right can be broken 


\section{SASDAYA}

Gadjah Mada Journal of Humanities, Vol. 5. No. 2, 2021

down into two clauses as shown in the picture above. The transitivity analysis in the first clause is a relational process because it contains the meaning of explaining the participants. Meanwhile, the second clause is a Mental process because it includes feelings about the truth. Furthermore, in the analysis of Interpersonal meaning, there is a difference between the two clauses. The first clause is in the form of a declarative with subject pattern followed by a predicator in order to convey information. The second clause is in the interrogative form with the predicator pattern before the subject in order to ask for confirmation regarding to the information. The choice of words is by using the phrase 'yang bawah' or the bottom. The phrase has ambiguity. If it is true that the sender of the message does not lead to sexuality, the sender can use the word 'foot' as it is the bottom part of the body, instead of ambiguity phrase or the sender does not need to associate the word with other things. Thus, since it is intended to give a sexual signal, the sender used those phrases which refer to the vitals.

Next, Figure 6 below is the visual element that following the verbal mode in Datum 2. The emoji used by perpetrator in the message especially is called as See no evil.

Figure 7 Ideational and Interpersonal Analysis Visual Mode Datum 2

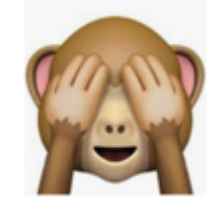

See no evil emoji is not included in the face emoji, but rather an animal emoji since it shows a monkey covering its eyes with both hands. The representational analysis or ideational analysis of emoji is limited to conceptual representations, especially to the suggestive symbolic process. The represented participants are not bound by time, and only one participant appears, namely the emoji itself. Universally, this emoji has the meaning of conveying laughter, disbelief, and horror. The analysis of Interpersonal meaning begins with the absence of eye gaze, which means it contains an offer. Then, the size of the frame in this emoji is the same as the previous emoji, namely a close shot with an eye-level angle.

By combining the interaction between verbal and visual modes, the result obtained is visual mode also extends the verbal sign in the message. The first idea is emoji, which states a distrust opinion because there is no truth from the intended party. However, when using the context of emoji in Indonesia, it contains the meaning of feeling embarrassed, so it is included in the emotive function. The utterance may seem to possess a positive attitude because it includes the meaning of praise. Still, with the chosen emoji and the phrase 'yang bawah' or the bottom, the attitude seems to contain negative implications. Thus, the perpetrator feels ashamed because his opinion has inappropriateness and can also describe the perpetrator's condition who is imagining something that leads to the sexual intention with words that lead directly to the genitals.

Moreover, there are some other utterances stated by perpetrator, such as 'bulet badannya saya lihat.. - or look at the curves, 'waduh.. suka main kasar ya kak 상' or wow, you seem to play it with rough way, aren't you?, 'saya kirim foto titit saya barangkali kakak minat fret' or I have sent the picture of my penis if you are interested, 'saya remes enak eughh mmhh,.. saya ngebayangin frat or I grab your boobs, damn mmh... I'm imagine it. From the analysis of 
all eight messages in verbal modes found can be divided into 12 clauses and 4 types of emoji, the results can be seen in the following Table 1 and Table 2 below.

Table 1 The Result of The Analysis of Ideational and Interpersonal Meaning of Verbal mode

\begin{tabular}{|l|l|l|l|l|}
\hline No. & Datum & \multicolumn{1}{|c|}{$\begin{array}{l}\text { Ideational } \\
\text { Meaning }\end{array}$} & \multicolumn{2}{|c|}{ Interpersonal Meaning } \\
\cline { 3 - 5 } & \multicolumn{1}{|c|}{ Process } & \multicolumn{2}{|c|}{ Mood } \\
\hline 1. & $\begin{array}{l}\text { Pipinya [berbentuk] } \\
\text { tembem banget }\end{array}$ & Relational & Subject + Predicator & Declarative \\
\hline 2. & $\begin{array}{l}\text { Pasti yang bawah } \\
\text { jugarbentuk } \\
\text { tembem banget] }\end{array}$ & Relational & Subject + Predicator & Declarative \\
\hline 3. & $\begin{array}{l}\text { [Pernyataan } \\
\text { sebelumnya] ya } \\
\text { (benar) [kan] kak? }\end{array}$ & Mental & Predicator + Subject & Interrogative \\
\hline 4. & $\begin{array}{l}\text { Bulet badannya saya } \\
\text { lihat }\end{array}$ & Mental & Subject + Predicator & Declarative \\
\hline 5. & $\begin{array}{l}\text { Bulet [merupakan } \\
\text { bentuk] badannya }\end{array}$ & Relational & Subject + Predicator & Declarative \\
\hline 6. & $\begin{array}{l}\text { [Kakak] suka main } \\
\text { kasar }\end{array}$ & Mental & Subject + Predicator & Declarative \\
\hline 7. & $\begin{array}{l}\text { [Pernyataan } \\
\text { sebelumnya] ya } \\
\text { (benar) [kan] kak? }\end{array}$ & Mental & Predicator + Subject & Interrogative \\
\hline 8. & $\begin{array}{l}\text { Saya kirim foto titit } \\
\text { saya }\end{array}$ & Material & Subject + Predicator & Declarative \\
\hline 9. & $\begin{array}{l}\text { Barangkali kakak } \\
\text { minat }\end{array}$ & Mental & Subject + Predicator & Declarative \\
\hline 10. & Saya remas & Material & Subject + Predicator & Declarative \\
\hline 11. & {$[$ [Saya merasa] enak } & Mental & Subject + Predicator & Declarative \\
\hline 12. & Saya ngebavangin & Mental & Subject + Predicator & Declarative \\
\hline
\end{tabular}

From the Table 1, it can be seen most of the data contain declarative mood. It means the perpetrator trying to inform and declare something. Not only declarative form, the use of interrogative form is to reinform or to ask information. Then, the most process that the perpetrator used is mental process. It can be conclude that the used of mental proses is reflecting the sensing of the perpetrator. For example, the use of the verb 'lihat' see, 'suka' like, 'merasa' feel, 'ngebayangin' imagine, and so on. The idea of the mental process can be related with the material process in order to construct as an act. The example of material process such as 'kirim' send, 'remas' squeeze. Next, the use of relational process it can be related with how the perpetrator connected into something such as 'merupakan' and 'menyerupai' like.

Table 2 The Results of The Analysis of The Ideational and Interpersonal Meaning of Visual

Mode

\begin{tabular}{|c|c|c|c|c|c|}
\hline \multirow[t]{2}{*}{ No. } & \multirow[t]{2}{*}{ Datum } & \multirow{2}{*}{$\begin{array}{l}\text { Ideational Meaning } \\
\text { (Representational) }\end{array}$} & \multicolumn{3}{|c|}{ Interpersonal Meaning } \\
\hline & & & Range & $\begin{array}{l}\text { Size of } \\
\text { Frame }\end{array}$ & Angle \\
\hline 1. & & $\begin{array}{l}\text { - Narrative Representation } \\
\text { Reactional especially non- } \\
\text { transactional } \\
\text { - Conceptual Representation } \\
\text { especially Suggestive } \\
\text { Symbolic } \\
\end{array}$ & Demand & Close shot & Eye level \\
\hline 2. & & $\begin{array}{l}\text { - Conceptual Representation } \\
\text { especially Suggestive } \\
\text { Symbolic }\end{array}$ & Offer & Close shot & Eye level \\
\hline 3. & & $\begin{array}{l}\text { Narrative Representation } \\
\text { Reactional especially non- } \\
\text { transactional } \\
\text { - Conceptual Representation } \\
\text { especially Suggestive } \\
\text { Symbolic } \\
\end{array}$ & Offer & Close shot & Eye level \\
\hline 4. & & $\begin{array}{l}\text { Narrative Representation } \\
\text { Reactional especially non- } \\
\text { transactional } \\
\text { Conceptual Representation } \\
\text { especially Suggestive } \\
\text { Symbolic } \\
\end{array}$ & Demand & Close shot & Eye level \\
\hline
\end{tabular}

From the Table 2, it can be seen that the use of face emoji is the most emoji used in data. Besides, the emoji is also used in multiple times. However, it still needs further analysis if the researcher concerning in the way emoji appeared in multiple times.

Thus, it can be conclude that visual mode in the form of emojis that can clarify verbal sexual harassment. It can be seen from the presence of visual signs that extend and explain the verbal 


\section{SASDAYA}

Gadjah Mada Journal of Humanities, Vol. 5. No. 2, 2021

mode. If the perpetrator did not use emoji in every single message, there could not be found any indication of verbal sexual harassment. Furthermore, the finding is also proving that the use of emojis can be a source of evidence in solving language crimes through social media.

The analysis results are also supported by the presence of secondary data or comments from the victim's uploaded tweets in the following screenshots in Figure 8 below.

Figure 8 Secondary Data Research on Comments about The Screenshot Indicates Sexual Harassment

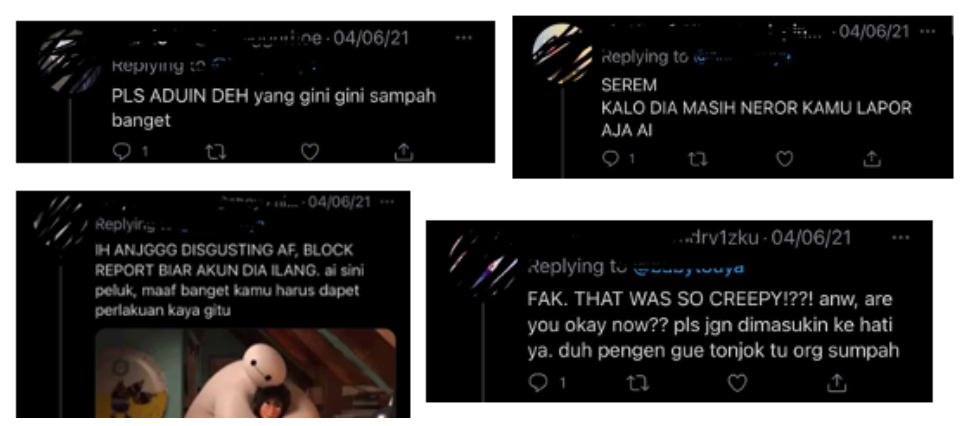

Looking at the context of the screenshot above reinforces the existence of verbal sexual harassment conveyed in the data. Thus the senders or the perpetrators acted and were not in a state of joke or just for fun. Moreover, the perpetrator and the victim (the message recipient) are only mutual or friends through social media. They are not have any special relationship. Then, the use of secondary data to validate the result of analysis. All of the secondary data said that the message which send by anonymous account or perpetrator is contain sexual harassment. It also can be seen in Figure 8. The use of "plis aduin deh", "lapor aja" please report it to the police, "block report aja" block the account, and that was so creepy. Those phrase can be understood as disappointment from the victim's mutual in social media. Thus, it can be an evidence that the messages contain sexual harassment through language. This findings is also supported by a statement of Danesi regarding the use of emoji, which can be a source of evidence to reveal language crimes through social media (Danesi, 2017).

If the researcher takes a look at the result of the previous studies, the researcher agrees that the use of emoji in social media can be interpreted in various way. It depends on the theory that we used to analyse and the purpose that we arranged of the research. The use of emoji is also cannot be used in another country. Different culture of a country means different meaning the use of an emoji. Then, it is important to be careful when using the emoji in any aspect. In fact, the use of emoji by an individual also can lead to misinterpret. Emoji can contain lots of meaning behind.

Both visual and verbal elements in a discourse is important because every element conveys something. Therefore, it is important to analyse both elements if we want to comprehend overall meaning of a discourse like a previous studies doing analysis on advertisement. The successful advertisement is because of elaboration between visual and verbal elements. One of the elements can be extend, elaborate, and enhance another elements depends on the data. For example, the visual mode can be extend instead of verbal mode but the verbal mode can be elaborate instead of visual mode and so on. For this verbal sexual harassment case, it relates with how visual elements is being the most important role such in advertisement case. 


\section{SASDAYA}

Gadjah Mada Journal of Humanities, Vol. 5. No. 2, 2021

The use of multimodal theory in order to reveal sexual harassment especially verbal sexual harassment is such a good choice. It depends on the elements that can be found in data. If the data consists of visual and verbal elements it is suitable using the theory. Therefore, the researcher also concludes that visual and verbal elements can be used in linguistic research. It is also challenging because forensic linguistics is a new theory. Then, it still need a further research. In short, the researcher agrees with the result of the previous studies that explained before.

\section{CONCLUSIONS}

From the analysis results, it was found that the visual mode in the form of an emoji used by the senders or perpetrators against the victim can extend and explain the verbal mode. Meanwhile, the extension means that there are new ideas contained in the emoji. Explaining the verbal mode here means that several verbal modes have an ambiguity that the presence of visual mode that can clarify. Through the results of a multimodal analysis of the two modes combined with the secondary data as supporting evidence, the message sent by the perpetrators via Instagram DM (Direct Message) can be said to be a form of verbal sexual harassment. Further, it can be entangled in the relevant article but it also has several problems if we take a look at the sender perspective.

Besides, the relationship between the elements that can be found in data is important. Both verbal and visual elements can convey a meaning behind in a discourse. It can be visual or verbal elements that can be extend, elaborate, and enhance verbal mode depends on the data. Moreover, it is important to remember that there are several aspects which is verbal and visual elements that needed in analysing using multimodal approach. Therefore, the use of multimodal approach in analysing data can be used in forensic linguistics field.

\section{REFERENCES}

Alexander, M., \& Halliday, K. (2014). Language as social semiotic. In The Discourse Studies Reader: Main Currents in Theory and Analysis. John Benjamins Publishing Company. https://doi.org/10.1075/z.184.53hal

Creswell, J. W. (2002). Research Design Qualitative, Quantitative, and mixed methods approaches (2nd ed.). SAGE Publications.

Danesi, M. (2017). The Semiotics Of Emoji. Bloomsbury Academic. www.semioticon.com/semiotix]

Frommer, D. (2021). Here's how to use Instagram. www.businessinsider.com

Halliday, M. A. K. (2014). Halliday's Introduction to Functional Grammar (4th ed.). Routledge.

Hidayat, D. N., A, A., \& A, A. (2019). A Multimodal Discourse Analysis of the Interpersonal Meaning of a Television Advertisement in Indonesia. IJEE (Indonesian Journal of English Education), 5(2). https://doi.org/10.15408/ijee.v5i2.11188

Komnas Perempuan National Commission On Violence Against Women. (2021). Perempuan Dalam Himpitan Pandemi: Lonjakan Kekerasan Seksual, Kekerasan Siber, Perkawinan Anak, dan Keterbatasan Penanganan di Tengah COVID- 19 CATAHU 2021: Catatan 


\section{SASDAYA}

Gadjah Mada Journal of Humanities, Vol. 5. No. 2, 2021

Tahunan Kekerasan Terhadap Perempuan Tahun 2020. National Commision On Violence Against Women. https://komnasperempuan.go.id/uploadedFiles/1466.1614933645.pdf

Kress, G., \& Leeuwen, T. van. (2006). Reading Images The Grammar of Visual Design (2nd ed.). Routledge.

Oktario, A. S., Ariesta, R., \& Gumono. (2019). Penggunaan Bahasa dalam Pesan Whatsapp: Interaksi Multimodal. Jurnal Ilmiah Korpus, 3(2), 131-136. https://www.google.com/url?sa=t\&rct=j\&q=\&esrc=s\&source=web\&cd=\&ved=2ahUKEwj6I-

dtLD1AhXZ8XMBHVDnDAcQFnoECAMQAQ\&url=https\%3A\%2F\%2Fejournal.unib.ac .id\%2Findex.php\%2Fkorpus\%2Farticle\%2Fdownload\%2F10113\%2F5060\&usg=AOvVaw 39IzeGwE16NSyZ2ile9WhR

Olsson, J. (2008). Forensic Linguistics (2nd ed.). Continuum.

Robbins, S. P. dan T. A. (2014). Perilaku Organisasi. In Salemba Empat (16th ed.).

Rosa, R. N. (2014). Analisis multimodal pada iklan Sunsilk Nutrien Sampo Ginseng. Kajian Linguistik, 12(2).

Shuy, R. (2012). The Language Of Sexual Misconduct Cases. Oxford University Press.

Suprakisno, S. (2010). Analisis multimodal iklan “Indomie .” Jurnal BAHAS, 26(1).

Yus, F. (2020). Chapter 3. Cyberpragmatics in the age of locative media. John Benjamins Publishing Company. https://doi.org/10.1075/pbns.318.03yus

Yuwono, U. (2019). Gramatika Fungsional Sistemik dan Penerapannya dalam Pemerian Bahasa. https://www.researchgate.net/publication/332833672_GRAMATIKA_FUNGSIONAL_SI STEMIK_DAN_PENERAPANNYA_DALAM_PEMERIAN_BAHASA 